\title{
Zooplankton from shrimp culture ponds in Northeastern Brazil
}

\author{
F. F. Porto Neto ${ }^{1}$, S. Neumann-Leitão ${ }^{2}$, M. Casé ${ }^{2,3}$, \\ E. E. Sant'Anna ${ }^{4}$, E. H. Cavalcanti ${ }^{5}$, R. Schwamborn ${ }^{2}$, \\ L. M. O. Gusmão ${ }^{2}$ \& P. A. M. C. Melo ${ }^{2}$ \\ ${ }^{1}$ Department of Zootecny, \\ Federal Rural University of Pernambuco, Brazil \\ ${ }^{2}$ Department of Oceanography, \\ Federal University of Pernambuco, Brazil \\ ${ }^{3}$ Department of Education, Bahia State University, Paulo Afonso, Brazil \\ ${ }^{4}$ Department of Biology, Federal University of Ouro Preto, Brazil \\ ${ }^{5}$ Department of Biology, Federal University of Alagoas, Brazil
}

\begin{abstract}
Zooplankton was examined in 14 commercial shrimp Litopenaeus vannamei ponds in tropical Brazil to assess their composition, determine their density, and indicate environmental quality. In each farm, two ponds and the water intake point were monitored in 2003. Sampling was made with a standard plankton net 50 micrometers mesh size. The zooplankton presented 40 taxa and was essentially composed of typical marine euryhaline species and suspensionfeeding forms. In all farms the dominant group was Copepoda with a total of $45 \%$, followed by Protozoa (18\%). The most abundant meroplankton were Polychaeta larvae, Gastropoda larvae, nauplii of Cirripedia and zoeae of Brachyura with large distribution in the region, sometimes dominating the community. Zooplankton abundance varied from $972 \pm 209$ ind $\mathrm{m}^{-3}$ to $4,235 \pm$ 2,877 ind $\mathrm{m}^{-3}$. In the studied marine shrimp culture ponds, copepods dominance were replaced by protozoan and rotifers as nutrient concentrations increased with the culture period, indicating that zooplankton trophic structure can be strongly affected by the occurrence of eutrophic conditions in shrimp ponds. The tendency of low species diversity is indicative of an unbalanced hypereuthrophic system decreasing the water quality and the cultured species. These results can be an important appointment to understand the effects of eutrophication in coastal plankton structure and its effects to marine aquatic food web.
\end{abstract}

Keywords: zooplankton, aquaculture, shrimp ponds, Litopenaeus vannamei. 


\section{Introduction}

Shrimp farming in Northeastern Brazil has increased exponentially during the past 10 years from an annual production of about 7,000 tons, produced in less than 1000 ha of pond area in 1998 to over 90,000 tons produced in about 15,000 ha of pond area in 2003 [1].

Although farmed shrimp now represent about $50 \%$ of the penaeid shrimp supply, farmers have suffered significant economic losses over the last decade. Reasons for decline include lack of knowledge about farming techniques, poor farm management practices, degradation of environment/water quality through industrial pollution/discharge, and (most importantly), shrimp disease. In Brazil, mortalities of cultured shrimp due to Idiopathic Abdominal Necrosis have resulted in significant economic losses, and it is now spreading throughout Northeastern region.

The water quality associated with aquaculture developments is an important concern globally as a variety of negative environmental impacts on the receiving environment have been documented [2]. Most importantly, it is the water quality that will influence optimal shrimp growth and yield. Classically, an investigation of water quality involves a combination of physical variables and biological indicators [3]. The fact that intensive mariculture often involves the addition of various feeds, fertilizers and chemicals to stabilize the earthen pond bottoms, the use of only classic physicochemical variables to accurately assess the water quality in and around these systems may be insufficient. Additionally, there is still little information on the use of the plankton community as biological indicators of water quality associated with culture systems. Consequently, this research would provide more data on the use of zooplankton as indicators of water quality. Zooplankton clearly contributes to the nutrition of shrimp postlarvae immediately after stocking [4]. Overall, this paper will be able to provide useful baseline water quality data that may enable the improvement of farm management processes.

\section{Materials and methods}

This research was based in 108 zooplankton samples collected during three campaigns from October $10^{\text {th }}$ to November $19^{\text {th }} 2003$ in 14 farms that intensively cultivate the marine shrimp Litopenaeus vannamei. Campaign 1 was carried out from 19 to 25/October; Campaign 2 from 01 to 07/November; Campaign 3 from 14 to $17 /$ November. In each farm, two ponds and the water intake point were monitored. The studied farms are located in Ceará, Piauí and Rio Grande do Norte states - Brazil (Fig. 1, Table 1). The farms produce shrimp by intensive culture (30 to 120 shrimps. $\mathrm{m}^{-2}$ ), feeding exclusively with balanced ration.

Zooplankton sampling at each station was collected with a standard plankton net with mesh size of 50 micrometers fitted with a flowmeter (Hydrobios, Kiel); 3 minutes horizontal subsurface hauls were made at each pond. Samples were preserved in a $4 \%$ buffered formalin/seawater solution. Zooplankton species were identified until the lowest taxonomic unit possible and taxon abundance 


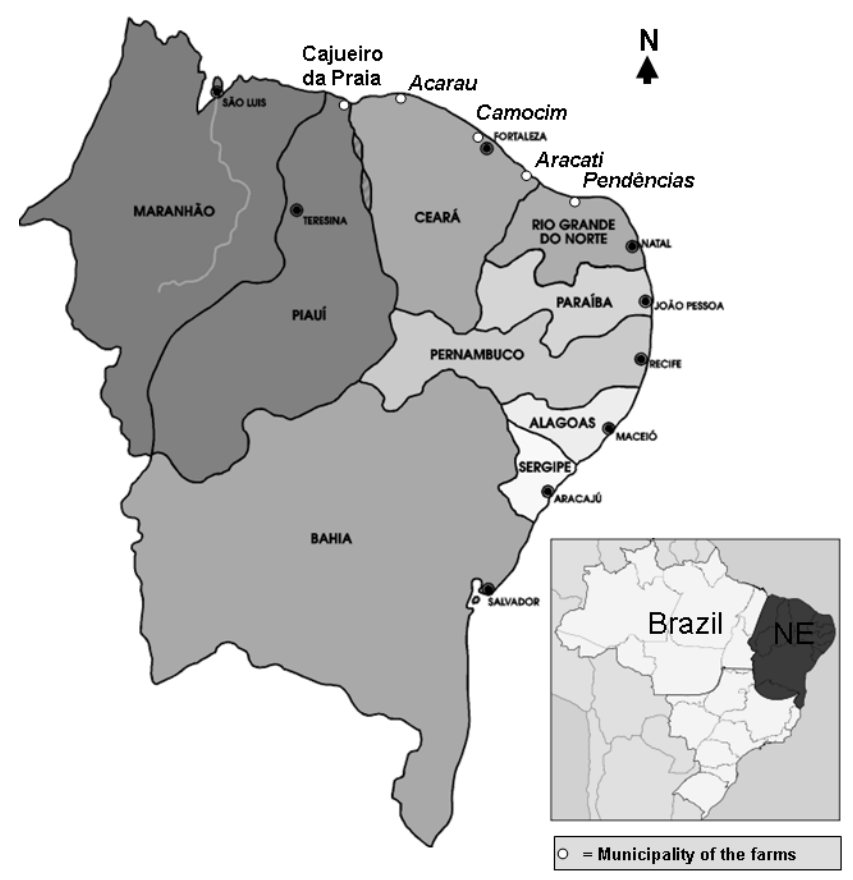

Figure 1: $\quad$ Study area of shrimp culture in Northeastern Brazil.

Table 1: $\quad$ Shrimp culture farms in Northeastern Brazil.

\begin{tabular}{|c|c|c|}
\hline FARMS (City) & Latitude & Longitude \\
\hline Ceará State & & \\
\hline $\begin{array}{l}\text { Promares, } \\
\text { (Camocim) }\end{array}$ Aquafort and Samarisco & $2^{\circ} 54^{\prime} \mathrm{S}$ & $40^{\circ} 50^{\prime} \mathrm{W}$ \\
\hline Papagaio, AS Marine and Joli(*) (Acaraú) & $2^{\circ} 50$ 's & $40^{\circ} 07^{\prime} \mathrm{W}$ \\
\hline Compescal, Cina and Vip Camarões (Aracati) & $4^{\circ} 33$ 's & $37^{\circ} 46^{\prime} \mathrm{W}$ \\
\hline $\begin{array}{l}\text { Piauí State } \\
\text { Camapi, Secom and Camarões do Brasil } \\
\text { (Cajueiro) }\end{array}$ & $2^{\circ} 55^{\prime} \mathrm{S}$ & $41^{\circ} 20^{\prime} \mathrm{W}$ \\
\hline $\begin{array}{l}\text { Rio Grande do Norte State } \\
\text { Potiporã }(*), \quad \operatorname{MRG}(*) \text { and Aquática }(*) \\
\text { (Pendências) }\end{array}$ & $06^{\circ} 16^{\prime} \mathrm{S}$ & $35^{\circ} 29^{\prime} \mathrm{W}$ \\
\hline
\end{tabular}

(*) Samples collected during the $2^{\text {nd }}$ and $3^{\text {rd }}$ campaigns.

(per cubic meter) counted under a microscope ( $1 \mathrm{~mL}$ subsample). These samples were taken with a Stempel-pipette of each the entire sample $(250 \mathrm{~mL})$.

The Shannon index $\left(\mathrm{H}^{\prime}\right)$ was applied for the estimation of zooplankton community diversity based on $\log _{2}$ [5]. Evenness was calculated according to Pielou [6]. 


\section{Results}

The zooplankton was essentially composed of typical marine euryhaline species, distributed in 40 taxa. The following Phyla were present: Sarcomastigophora, Cnidaria, Nematoda, Rotifera, Mollusca, Annelida, Crustacea, Bryozoa and Chordata. The dominant taxa were Copepoda (16 species and made up 44\% of relative abundance) as adult and juvenile forms (nauplii and copepodits), followed by Protozoa (18\%) and Rotatoria (6 species with $12 \%$ of total relative abundance) (Fig. 2). The meroplankton was represented by Polychaeta larvae (dominated by spionids), Gastropoda and Bivalvia larvae, nauplii of Cirripedia and zoeae of Brachyura with large distribution in the region, sometimes dominating the community.

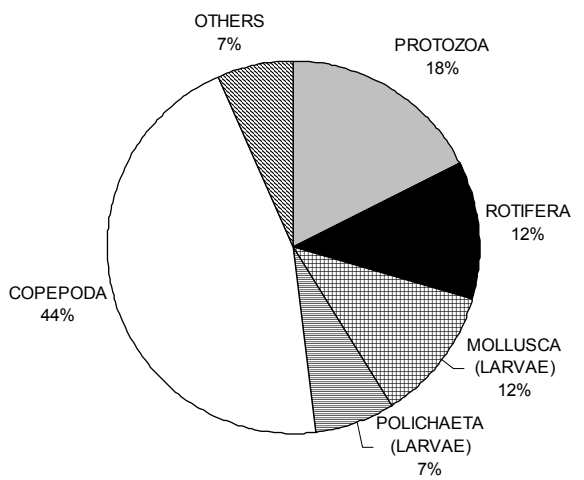

Figure 2: Relative abundance of the main zooplankton groups in shrimp culture ponds.

Among Copepoda predominated Parvocalanus crassirostris, Acartia lilljeborgi, Oithona oswaldocruzi, Oithona hebes and Euterpina acutifrons.

Protozoa was mainly represented by the atecate ciliata and the tintinnina Tintinnopsis spp. and Favella ehrenbergi.

Rotifers presented high quantities of Brachionus plicatilis in the aquaculture ponds. Many stages of Nematoda, found at Cina and Papagaio farms belonged to Ancylostoma duodenale and according to Rey [7] the larvae develop in the aquatic environment, at the rainy season, between temperatures between 23 and $30^{\circ} \mathrm{C}$ and the adults develop well in humid soil rich in organic residuals.

In general, species diversity was low. Lowest diversity index was found in Aquafort farm (1.26 bits.ind $\left.{ }^{-1}\right)$ and the highest at Promares farm (1.75 bits.ind b $\left.^{-1}\right)$. Minimum evenness was registered at Aquafort farm $(0.44)$, caused by the dominance of few species (mainly atecate ciliata and Copepoda nauplii) and the maximum was 0.6 at Vip Camarões farm.

Zooplankton total density was high with a minimum of 3,875 org. $\mathrm{m}^{-3}$ (Aquática farm) and a maximum of 12,706 org. $\mathrm{m}^{-3}$ (Compescal farm). The average zooplankton abundance varied from $972 \pm 209$ ind. $\mathrm{m}^{-3}$ to $4,235 \pm 2,877$ ind. $\mathrm{m}^{-3}$ (Fig. 3), with an average of $2255 \pm 975$ ind. $\mathrm{m}^{-3}$. 


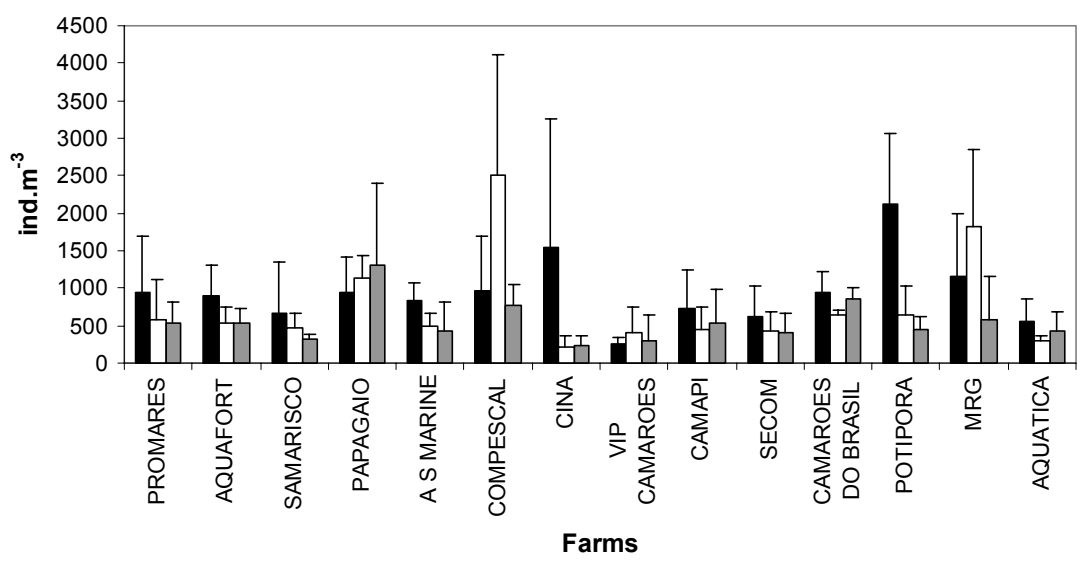

- Intake point $\square$ Pond $1 \square$ Pond 2

Figure 3: Zooplankton density from shrimp culture ponds in Northeastern Brazil.

In a general way, the intake points presented better conditions than most ponds, in which dominated many times organic pollution indicators (atecates ciliates, rotifers, polychaeta larvae, nematode, among others). Even presenting strong organic decomposition charge, there were copepod nauplii, and Bivalve larvae in high densities, showing the great importance of the marine flux in renewing the environment and improvement of environmental health.

\section{Discussion}

The use of physicochemical indicators exclusively to assess the water quality of intensive mariculture system is insufficient mainly if there is an investigation into the extent of the influence of the farm wastewater on the immediate environs. Previous studies that conclude that the use of traditional water quality indices to determine the effect of aquaculture effluent on the receiving environment is mainly limited to areas near to the discharge point $[8,9]$.

We considered zooplankton indices to be useful water quality indicators for the shrimp culture facility and its immediate environs. This was on the basis that there were fairly distinct patterns in the species composition and abundance as the water quality changed spatially and temporally. This may be attributed to the fact that the zooplankton community itself responds directly or indirectly to changes in the physicochemical variables and the availability of phytoplankton food [10] and is therefore less affected by manipulation via farm management processes.

This study examined the seasonal and tidal variation of microzooplankton in Northeastern shrimp farms to develop a more comprehensive understanding of the zooplankton role in these conditions. In general, little is known about the 
zooplankton dynamics in tropical estuaries, and according to Buskey [11], zooplankton rarely have been studied concurrently in tropical or temperate estuaries, even less studies exists on shrimp ponds.

Studies of zooplankton in shrimp ponds have shown that these are complex assemblages with rapid temporal changes in structure [4]. The main factors influencing these changes are variations in source of food, predation and the influences of variations in physical and chemical water quality parameters. The results here described reveals that nutrient input affected both density and the relative species composition of the zooplankton community. Therefore zooplankton assemblages could be an excellent bioindicator of water quality of shrimp ponds.

The dominant taxa were Copepoda and predominated the Brazilian eurihaline-estuarine indicators formed by Parvocalanus crassirostris, Acartia lilljeborgi, Oithona oswaldocruzi, Oithona hebes and Euterpina acutifrons $[12,13]$.

Acartia lilljeborgi had an important role in July (rainy season) in Sergipe River estuary and this may be related to the high amount of detritus occurring in this season that is consumed by this species, as has been demonstrated through stable isotope measurements and feeding experiments performed in laboratory and in situ [14,15]. Parvocalanus crassirostris was important in July and it is very common in most Brazilian estuaries [12] even those dramatic impacted [16,17]. Parvocalanus crassirostris feeds significantly on picoplankton and nanoplankton and behaves as opportunistic particle feeder, showing higher consumption rates upon the most abundant cells (2-5 $\mu$ m nanoplankton) [18]. Generally it is an abundant species in euthrophic systems.

Copepods and other crustaceans, larvae of polychaetes, larvae of insects, mollusks (Bivalvia and Gastropoda larvae), ostracods, rotifers have been considered the most important sources of food for shrimp [19-21, among others). The assemblages found in the studied ponds have a variety of roles within the pond ecosystem. Grazing zooplankton influences the dynamics of pond phytoplankton [4]. Predation of zooplankton by shrimp [22] may transfer a significant proportion of the nutrients from natural biota to the shrimp [23].

Tintinnids constitute important component of the planktonic microprotozoan community in most marine environments [24,25], and they can be important occasionally in estuarine waters [26]. High abundance, fast reproduction rates, and short generation times, coupled with the high capacity to use a large spectrum of food resources, enhance the importance of tintinnids as a key trophic link between the microbial and the metazoan compartments [26-28].

Some species have an apparent cosmopolitan distribution in the seas and oceans. Favella ehrenbergii has been commonly found in costal and estuarine areas in Brazil, with a high density in some periods [29-31]. The singular higher values of $F$. ehrenbergii densities were responsible for the structure disturbance of the microzooplankton community (negative contribution to the Shannon's diversity index) in the present study. The diet of $F$. ehrenbergii is composed mainly of nanoflagellates [32]. This species occurs in regions with high temperature and wide salinity ranges [33]. 
Ciliated protozoa are widely distributed in the aquatic environment and play an important role in the energy flow of aquatic ecosystems, as predators of bacteria, algae, and fungi, and as a food source for metazoa, such as fish and shrimp larvae [34]. However, their occurrence and role in shrimp production systems have seldom been investigated. Bratvold et al. [35] reported that the zooplankton from intensive shrimp production systems were dominated by ciliates, at least during part of the production cycle. Decamp et al. [36] reported that ciliates could reach extremely high concentrations (as much as 6000 cells $\mathrm{mL}^{-1}$ ) in zero-water exchange systems, with fluctuations in abundance reflecting the impact of water salinity, dynamic interactions between ciliates, and their diverse roles within the shrimp production system.

Among the registered rotifers outranked Brachionus plicatilis in the aquaculture ponds. Rotifers are valuable live food for larval fish and crustacean culture and also have been used as indicators of trophy. Several characteristics of rotifers, including their nutritional quality, body size and relatively slow motility have contributed to their usefulness as good prey for active larvae [37]. The rotifer Brachionus plicatilis has been most widely used as essential food source in raising marine fish, shrimp and crab larvae due to its tolerance to the marine environment [38]. The rotifer B. plicatilis is a euryhaline species and in nature, density peaks of these species are associated with high eutrophication near village and/or processing plants of aquatic and/or poultry products [39]. $B$. plicatilis and others rotifers species dominated the estuarine region of the Ipojuca River (Northeastern Brazil) that receives high sewage loads from many cities and industries [29].

Neumann-Leitão and Matsumura-Tundisi [40] reported the importance of the marine flux renewing the zooplankton community in a highly impacted estuary in Northeastern Brazil.

It can be concluded that the high amount of atecate ciliates, mainly in two farms indicated a poor water quality. In general, the colonization by ciliates occurs associated to the high levels of organic matter. The dominance of these species in the ponds can favor the bacterioplankton control and add additional food to the ponds. However, in high quantities as presently found in the ponds indicated an enriched organic matter environment, and the effluent of theses ponds can negatively impact the water of the receptor area. In one farm, it was registered a Mysis stage with ectoparasites protozoan as Vorticella spp. These parasites affect negatively the molts and the development of the infected organisms, a fact that was observed in this farm and also in another farm where parasitic nematodes were registered. Thus, it is most recommended to implant an environmental education program to the shrimp culture farmers, in order to introduce better management practices.

\section{References}

[1] Madrid, R. M., 2004. Influência do meio ambiente em áreas de risco na qualidade bacteriológica do camarão cultivado no Estado do Ceará. LABOMAR/UFC, Fortaleza, 233 p. 
[2] Landesman L. 1994. Negative impacts of coastal Aquaculture development. World Aquaculture 25: 12-17.

[3] Jones, A. B., Jones, M. J., O’Donohue, J. \& Denninson, W. C. 2001. Assessing ecological impacts of shrimp and sewage effluent: biological indicators with Standard water quality analysis. Estuarine, Coastal and Shelf Science 52: 91-109.

[4] Coman, F. E., Connolly, R. M. \& Preston, N. P. 2003. Zooplankton and epibenthic fauna in shrimp ponds: factors influencing assemblages dynamics. Aquaculture Research 34, 359-371.

[5] Shannon, C. E. 1948. A mathematical theory of communication. Bell System Technical Journal 27: 379-423 and 623-656.

[6] Pielou, E. C. 1967. An introduction to Mathematical Ecology. WileyInterscience, New York. 286p.

[7] Rey, L. 2002. Bases da Parasitologia Médica. 2a. Ed., Rio de Janeiro: Guanabara Koogan.

[8] Hensey, M. P. 1991. Environmental monitoring for fish farms in Ireland. In Aquaculture and the Environment. (De Pauw, N. \& Joyce, J., eds). Special Publication of the European Aquaculture Society No. 16. Oxford, England. 536 pp.

[9] Samocha, T. M. \& Lawrence, A. L. 1995. Shrimp farms effluent waters, environmental impact and potential treatment methods. Proc. 24th U.S.Japan Aquaculture Panel Symposium, Corpus Christi, Texas, October 810, 1995.

[10] Raymont, J. E. G. 1980. Plankton and Productivity in the Oceans, vol. 1, Phytoplankton. Oxford, Pergamon Press.

[11] Buskey, E. J., 1993, Annual pattern of micro- and mesozooplankton and biomass in a subtropical estuary. Journal of Plankton Research 15: 907924.

[12] Björnberg, T. S. 1981. Copepoda. In: Boltovskoy, D. (Ed.), Atlas del zooplancton del Atlántico sudoccidental y métodos de trabajo con el zooplancton marino. INIDEP, Mar del Plata, pp. 587-679.

[13] Neumann-Leitão, S., Gusmão, L. M. O., Silva, T. A., Nascimento-Vieira, D. A. \& Silva, A. P. 1999. Mesozooplankton biomass and diversity in coastal and oceanic waters off North-Eastern Brazil. Archives of Fisheries and Marine Research 47, 153-165.

[14] Schwamborn, R. 1997. The influence of mangroves on community structure and nutrition of macrozooplankton in northeast Brazil. ZMT Contrib., Bremen, 4, 1-77.

[15] Schwamborn, R., Ekau, W., Voss, M. \& Saint-Paul, U. 1999. Stable isotope composition of particulate organic matter and zooplankton in Northeast Brazilian shelf waters. Archives of Fisheries and Marine Research 47: 201-210.

[16] Schwamborn, R., Bonecker, S.L.C., Galvão, I. B., Silva, T. A. \& Neumann-Leitão, S. 2004. Mesozooplankton grazing under conditions of extreme eutrophication in Guanabara Bay, Brazil. Journal of Plankton Research 26: 983-992 
[17] Silva, A. P., Neumann-Leitão, S., Schwamborn, R., Gusmão, L. M. O. \& Silva, T. A. 2004. Mesozooplankton of an impacted bay in North Eastern Brazil. Brazilian Archives of Biology and Technology 47: 485-493.

[18] Calbet, A., Landry, M. R., Scheinberg, R. D., 2000, Copepod grazing in a subtropical bay: species-specific responses to a midsummer increase in nanoplankton standing stock. Marine Ecology Progress Series 193: 75-84.

[19] Rubright, J. S., Harrel, J. L. \& Parker, J. C. 1981. Responses of planktonic and benthic communities to fertilizers and feed applications in shrimp mariculture ponds. Journal of the World Aquaculture Society 121, 281299.

[20] Schroeder, G.L. 1983. Sources of fish and prawn growth in polyculture ponds as indicated by $\Delta \mathrm{C}$ analysis. Aquaculture, 35:29-42.

[21] Allan, G. L., Moriarty, D. J. W. \& Maguire, G. B. 1995. Effects of pond preparation and feeding rate on production of Penaeus monodon Fabricus, water quality, bacteria and benthos in model farming ponds. Aquaculture 130: 329-349.

[22] Martinez-Cordova, L. R., Porchas-Cornejo, M. A., Villarreal-Colmenares, H. \& Calderon-Perez, J. A. 1998. Effect of aeration on chlorophyll a, zooplankton, and benthos in yellowleg shrimp, Penaeus californiensis ponds. Journal of Applied Aquaculture 8:17-23.

[23] Anderson, R. K., Parker, P. L. \& Lawrence, A. 1987. A ${ }^{13} \mathrm{C} /{ }^{12} \mathrm{C}$ tracer study of the utilization of presented feed by a commercially important shrimp Penaeus vannamei in a pond grow-out system. Journal of the World Aquaculture Society 18: 148-155.

[24] Pierce, R.W. \& Turner, J.T. 1992. Ecology of planktonic ciliates in marine food webs. Revue of Aquatic Science 6: 139-181.

[25] Pierce, R. W. \& Turner, J. T. 1993. Global biogeography of marine tintinnids. Marine Ecology Progress Series 94: 11-26.

[26] Urrutxurtu, I. 2004. Seasonal succession of tintinnids in the Nervión river estuary, Basque Country, Spain. Journal of Plankton Research 26: 307314.

[27] Capriulo, G. M. \& Carpenter, E. J. 1983. Abundance, species composition and feeding impact of tintinnid micro-zooplankton in Central Long Island Sound. Marine Ecology Progress Series 10: 277-288.

[28] Capriulo, G. M., Smith, G., Troy, R., Wikfors, G. H., Pellet, J. \& Yarish, C. 2002. The planktonic food web structure of a temperate zone estuary, and its alteration due to eutrophication. Hydrobiologia 475/476: 263-333.

[29] Neumann-Leitão, S., Paranaguá, M. N. \& Valentin, J. L. 1992. Ecology of Planktonic Rotifera of the Estuarine Lagunar Complex at Suape, Pernambuco (Brazil). Hydrobiologia 232:133-143.

[30] Lopes, R. M. 1994. Zooplankton distribution in the Guaraú river estuary (South-eastern Brazil). Estuarine, Coastal and Shelf Science 39: 287-302.

[31] Eskinazi-Sant'anna, E. M. \& Tundisi, J. G. 1996. Zooplâncton do estuário do Pina (Recife, Pernambuco, Brasil): composição e distribuição temporal. Revista Brasileira de Oceanografia 44: 23-33. 
[32] Bernard, C. \& Rassoulzadegan, F. 1993. The role of picoplankton (cyanobacteria and plastidic picoflagellates) in the diet of tintinnids. Journal of Plankton Research 15: 361-373.

[33] Godhantaraman, N. \& Uye, S. 2003. Geographical and seasonal variations in taxonomic composition, abundance and biomass of microzooplankton across a brackish-water lagoonal system of Japan. Journal of Plankton Research 25: 465-482.

[34] Nagano, N. \& Decamp, O. 2004. Ingestion of a ciliated protozoa by firstfeeding larval stage of Pacific white shrimp, Litopennaeus vannamei (Boone). Aquaculture Research 35: 516-518

[35] Bratvold, D., Lu, J. \& Browdy, C. L. 1999. Disinfection, microbial community establishment and shrimp production in a prototype biosecure pond. Journal of the World Aquaculture Society 30:422-432.

[36] Decamp, O., Conquest, L., Cody, J. \& Forster, I. 2007. Effect of Shrimp Stocking Density on Size-fractionated Phytoplankton and Ecological Groups of Ciliated Protozoa within Zero-water Exchange Shrimp Culture Systems. Journal of the World Aquaculture Society 38: 395-406.

[37] Snell, T. W. \& Carrillo, K. 1984. Body size variation among strains of the rotifer Brachionus plicatilis. Aquaculture 37: 359-367.

[38] Lubzens, L. 1987. Raising rotifers for use in aquaculture. Hydrobiologia 147: 245-255.

[39] Fenggi, L. 1996. Production and application of rotifers in aquaculture. Aquaculture Magazine 22: 16-22.

[40] Neumann-Leitão, S. \& Matsumura-Tundisi, T. 1998. Dynamics of a perturbed Estuarine Zooplanktonic Community: Port of Suape, PE, Brazil. Verhandlungen Internationale Vereinigung Limnologie 26: 1981-1988. 